\title{
PEMETAAN MEDIA MASSA DAN MEDIA SOSIAL SEBAGAI SALURAN KOMUNIKASI POLITIK PADA PILKADA KOTA TANJUNGPINANG 2018
}

\author{
${ }^{1}$ Uly Sophia, ${ }^{2}$ Noviwinarti \\ ${ }^{1,2}$ Program Sudi Ilmu Pemerintahan, Fakultas Ilmu Sosial dan Ilmu Politik \\ Universitas Maritim Raja Ali Haji \\ Email: usophia@gmail.com
}

\begin{abstract}
Abstrak
Dalam penyelenggaraan pemilihan walikota Tanjungpinag 2018 terdapat media komunikasi politik (kampanye) yang digunakan oleh kandidat. Seiring dengan berkembangnya globalisasi, penggunaan media sosial semakin tinggi. Bagaimana pemetaan media massa dan media sosial sebagai saluran komunikasi politik pada Pilkada Kota Tanjungpinang 2018. Penelitian ini bertujuan untuk mengetahui pola pemetaan media massa dan media sosial sebagai saluran komunikasi politik pada Pilkada tersebut. Metode yang digunakan dalam penelitian ini yaitu metode deskriptif dengan pendekatan kuantitatif, yang menjadi populasi di dalam penelitian ini yaitu seluruh DPS Pilkada Kota Tanjungpinang. Pengambilan sampel menggunakan teknik multi-stage stratified sample. Data diambil dengan menggunakan kuesioner dan wawancara, Hasil jawaban kuesioner kemudian disusun, dianalisa dan disajikan untuk memperoleh gambaran sistematis tentang kondisi dan situasi yang ada. Hasil penelitian sementara menunjukkan bahwa untuk kategori media Elektronik di dominasi oleh TanjungpinangTV sebesar 51\%, untuk kategori media Cetak maka Tanjungpinang Pos mendominasi dengan persentase sebesar 54\%. Kategori media Sosial di dominasi oleh Facebook dengan persentase $60 \%$.
\end{abstract}

Kata Kunci: Media, Media Sosial, Pilkada

\begin{abstract}
In organizing the election of the mayor of Tanjungpinag 2018 there are political communication media (campaigns) used by candidates. Along with the development of globalization, the use of social media is getting higher. How to map mass media and social media as political communication channels in the 2018 Tanjungpinang Regional Election. This study aims to determine the pattern of mass media mapping and social media as a channel for political communication in the Pilkada. The method used in this study is a descriptive method with a quantitative approach, which becomes the population in this study, namely the entire Tanjungpinang City Election DPS. Sampling using a multi-stage stratified sample technique. Data was taken using questionnaires and interviews, the results of the questionnaire answers were then compiled, analyzed and presented to obtain a systematic picture of the conditions and situations that exist. The results of the interim research show that for the category of Electronic media is dominated by TanjungpinangTV by 51\%, for the Print media category, Tanjungpinang Pos dominates with a percentage of 54\%. The Social media category is dominated by Facebook with a percentage of $60 \%$.
\end{abstract}

Keywords: Media, Social Media, Election

\section{PENDAHULUAN}

Perkembangan global teknologi informasi dan komunikasi (TIK) telah memicu pertumbuhan komunikasi dunia maya, baik di kalangan pemerintah, kelembagaan sosial politik, maupun di kalangan masyarakat. Perkembangan komunikasi itu ditandai oleh 
pemanfaatan media baru sebagai media komunikasi (new media). Komunikasi yang pada awalnya hanya sebatas proses interaksi personal secara face to face, kini berkembang secara online melalui iternet. Salah satu komunikasi berbasis internet yang banyak digunakan adalah media sosial. Media sosial adalah sebuah media online. Para penggunanya bisa dengan mudah berpartisipasi, berbagi, dan menciptakan isi. Jika media tradisional menggunakan media cetak dan media broadcast, maka media sosial menggunakan internet. Dengan demikian, media sosial sebagai sarana komunikasi memiliki peran membawa orang (penggunanya) untuk berpartisipasi secara aktif dengan memberi kontribusi dan feedback secara terbuka, baik untuk membagi informasi maupun memberi respon secara online dalam waktu yang bersamaan.

Pemilihan Kepala Daerah (pilkada) secara langsung bagian dari proses demokrasi. Tahun 2018 merupakan tahun politik bagi Kota Tanjungpinang, Propinsi Kepulauan Riau. Penyelenggaraan Pilkada untuk memilih Walikota dan Wakil Walikota. Proses pemilihan kepala daerah secara langsung ini, membutuhkan setiap penduduk kota Tanjungpinang yang memiliki hak pilih untuk berpartisipasi sehingga bermuara pada partisipasi untuk mempengaruhi proses pengambilan keputusan yang menyangkut kepentingan masyarakat kota Tanjungpinang selama lima tahun kedepan.

Bakal calon pasangan walikota dan wakil walikota Tanjungpinang serta merta akan menggunakan berbagai saluran komunikasi untuk menyampaikan gagasan-gagasannya atau kampanye. Rogers dan Storey dalam Venus (2012:7) mendefinisikan kampanye sebagai serangkaian tindakan komunikasi yang terencana dengan tujuan menciptakan efek tertentu pada sejumlah besar khalayak yang dilakukan secara berkelanjutan pada kurun waktu tertentu. Tujuan kampanye biasanya diarahkan untuk menciptakan perubahan pada tataran pengetahuan, yang kemudian diharapkan dapat menggugah kesadaran sehingga khalayak pada akhirnya berubah keyakinan atau meningkatnya pengetahuan khalayak tentang pesan, gagasan atau program pembangunan yang dijanjikan.

Dalam kampanye, media massa merupakan salah satu pemegang kekuatan politik di ranah intermediary, antara penguasa dan masyarakat. Sebagai aktor intermediary, media massa juga digunakan oleh masyarakat untuk mengakses dan mengetahui informasi politik. Sesuai dengan fungsi media massa menurut McQuail (2000: 66), yaitu media dipandang sebagai jendela yang memungkinkan khalayak melihat apa yang sedang terjadi di luar sana. Fenomena penggunaan media massa sebagai komunikasi politik juga terjadi di Kota Tanjungpinang, kedua pasang calon yang maju berkontestasi di dalam Pilkada Kota Tanjungpinang terlihat cukup banyak mensosialisasikan dan mengkampanyekan diri melalui media massa dan media sosial.

Berdasarkan hasil penelitian Fachrizan pada tahun 2015, media massa yang paling banyak digunakan sebagai kendaraan politik kampanye calon legislatif Kota Tanjungpinang yaitu berupa media cetak. Hal ini merupakan fenomena yang lumrah, karena media cetak merupakan media komunikasi yang sangat mudah diakses oleh semua kalangan. Namun, fenomena penggunaan media massa saat ini bergeser. Derasnya arus globalisasi membuat penggunaan media cyber semakin meningkat. Pada tahun 2016, jumlah pengguna internet di 
Indonesia mencapai 132,7 juta jiwa, atau sekitar 51,5\% dari total jumlah penduduk Indonesia yang berjumlah 256,2 juta jiwa.

Bahkan jika melihat laju perkembangan media sosial di Indonesia dalam satu dekade terakhir sangat mencengangkan. Dirangkum oleh Nugroho dan Syarief (2012:10), pengguna Facebook di Indonesia mencapai 42,5 juta penduduk, Twitter 19,5 juta, dan blog lebih dari 3,5 juta. Artinya, perilaku pengguna internet di Indonesia yang paling tinggi yaitu media sosial dengan konten utamanya Facebook.

Perkembangan teknologi informasi dan komunikasi yang berubah dengan cepat mentransformasi masyarakat dengan pertumbuhan jumlah informasi dan sejumlah perangkat yang semakin multimedia. Dalam konteks ini, bentuk perubahan yang terjadi pada lingkungan media memungkinkan orang mengkases informasi tidak hanya dengan membaca koran di kantor, mendengarkan siaran di radio atau melihat berita di televisi, hari ini masyarakat mampu mengakses keseluruhan dengan menggunakan perangkat multimedia dan jejaring internet. Artinya, dengan jumlah pengguna internet yang semakin banyak, media cetak yang merupakan media paling efektif untuk kampanye pada pemilu tahun 2014 dipertanyakan keefektifannya dalam menyampaikan pesan serta kampanye politik pada tahun 2018 di Kota Tanjungpinang.

Berikut lampiran rekapitulasi Daftar Pemilih Sementara Kota Tanjung Pinang tahun 2018, yaitu sebagai berikut:

Tabel 1. Rekapitulasi DPS Pilkada Kota Tanjungpinang 2018

\begin{tabular}{|c|l|c|c|}
\hline No & \multicolumn{1}{|c|}{ Nama Kecamatan } & $\begin{array}{c}\text { Jumlah } \\
\text { Kelurahan }\end{array}$ & Jumlah Pemilih \\
\hline 1 & Tanjungpinang Barat & 4 & 34.903 \\
\hline 2 & Tanjungpinang Kota & 4 & 15.366 \\
\hline 3 & Tanjungpinang Timur & 5 & 55.373 \\
\hline 4 & Bukit Bestari Jumlah & 5 & 38.599 \\
\hline \multicolumn{2}{|c|}{ Jur } \\
\hline
\end{tabular}

Sumber: KPU Kota Tanjungpinang, 2018

Berdasarkan fenomena di atas, tulisan ini akan memetakan pengguna media massa dan media sosial dalam mengakses informasi kampanye politik yang digunakan oleh pemilih dalam pilkada Kota Tanjungpinang tahun 2018.

\section{Pilkada dan Media Massa: Suatu Kajian Teoritis}

Menjadi negara yang demokratis, memiliki syarat antara lain yaitu adanya perlindungan konstitusional terhadap hak-hak warga negara, adanya pemilu yang bebas, kebebasan berserikat, berkumpul, menyatakan pendapat. Menurut Suryanti (2015: 125), apabila dilihat dari prinsip tatakelola pemerintahan yang baik, maka diperlukan partisipasi aktif warga masyarakat dalam pemerintahan, adanya penegakan hukum, pengaplikasian prinsip-prinsip transparansi, responsif terhadap kebutuhan masyarakat, menerapkan keadilan dan perlakuan yang sama untuk semua orang, pengelolaan kekuasaan yang efektif dan dapat 
dipertanggungjawabkan. Artinya, pemilihan kepala daerah yang selama ini dilaksanakan bertujuan untuk meningkatkan partisipasi masyarakat dalam kehidupan demokrasi, serta memperoleh kepala daerah yang benar-benar terlegitimasi oleh masyarakatnya. Dengan hipotesa tersebut, kepala daerah yang terpilih diharapkan mampu membangun daerah dan mengutamakan kesejahteraan rakyatnya.

Melihat dinamika pilkada, pasal 56 Undang-Undang Nomor 32 Tahun 2004 tentang Pemerintah Daerah, menyebutkan bahwa memilih kepala daerah di tingkat provinsi maupun kabupaten kota dilakukan melalui pemungutan suara secara langsung oleh masyarakat yang mempunyai hak pilih di wilayah yang menyelenggarakan pilkada, sehingga sering disebut dengan pilkada langsung. Namun dengan keluarnya Undang-Undang Nomor 22 Tahun 2007, pilkada langsung ini menjadi bagian dari rezim pemilu, maka istilah yang dipakai menjadi pemilukada.

Dinamika pemilukada silih berganti mewarnai penyelenggaraan pemilukada. Pada tahun 2015, istilah pemilukada berubah menjadi Pemilihan Gubernur dan Wakil Gubernur, Bupati dan Wakil Bupati dan Walikota dan Wakil Walikota dengan keluarnya UndangUndang Nomor 8 Tahun 2015. Nomenklatur ini secara esensial tidak mengubah tatacara pemilihan yaitu dilaksanakan secara langsung, meskipun pernah ada wacana untuk mengembalikan metode pemilihan kepala daerah ke tangan DPRD.

Tahapan penyelenggaraan Pilkada sesuai dengan pasal 6 Peraturan Komisi Pemilihan Umum Republik Indonesia Nomor 1 Tahun 2017 tentang Tahapan, Program dan Jadwal Penyelenggaraan Pemilihan Gubernur dan Wakil Gubernur, Bupati dan Wakil Bupati, dan/atau Walikota dan Wakil Walikota Tahun 2018, terdapat tahapan kampanye yang dilakukan dengan berbagai macam media komunikasi, di antaranya yaitu media massa, media elektronik dan media cetak. Artinya, tahapan kampanye merupakan hal yang turut menentukan penyelenggaraan pilkada dalam usaha menjaring suara pemilih bagi kandidat calon yang maju.

Sebuah proses komunikasi yang melibatkan tokoh politik dengan pesan-pesan politik kepada khalayaknya merupakan komunikasi politik. Pakar Politik Maswadi Rauf mendefinisikan komunikasi politik sebagai:

"Pesan-pesan yang diungkapkan dalam proses komunikasi bercirikan politik, yaitu berkaitan dengan kekuasaan politik negara, pemerintahan dan juga aktivitas komunikator dalam kedudukan sebagai pelaku kegiatan politik. Komunikasi politik dilihat dari dua dimensi yaitu komunikasi politik sebagai kegiatan politik dan sebagai kegiatan ilmiah. Komunikasi sebagai kegiatan politik merupakan penyampaian pesan-pesan yang bercirikan politik oleh aktor-aktor politik kepada pihak lain. Kegiatan tersebut bersifat empiris karena dilakukan secara nyata dalam kehidupan sosial. Sementara itu, komunikasi politik merupakan salah satu kegiatan politik dalam sistem politik”. (Pureklolon, 2016:3)

Dengan kata lain komunikasi politik merupakan produksi, proses dengan mengharapkan efek pada pengetahuan, sikap dan perilaku baik melalui media secara interpersonal atau massa dengan konteks politik. Salah satu bentuk dari komunikasi politik adalah kampanye, Rogers dan Storey dalam Venus (2012:7) mendefinisikan kampanye sebagai serangkaian tindakan komunikasi yang terencana dengan tujuan menciptakan efek 
tertentu pada sejumlah besar khalayak yang dilakukan secara berkelanjutan pada kurun waktu tertentu.

Kampanye yang berorientasi pada kandidat pada umumnya dimotivasi oleh hasrat untuk meraih kekuasaan politik, oleh karena itu jenis kampanye ini dapat disebut sebagai kampanye politik. Tujuannya antara lain untuk memenangkan dukungan masyarakat terhadap kandidat-kandidat yang diajukan partai politik agar dapat menduduki jabatanjabatan politik yang diperebutkan lewat proses pemilihan langsung.

Tidak terlepas dari proses kampanya, media massa hadir sebagai pemenuhan kebutuhan manusia akan informasi dan hiburan, baik tentang politik maupun lainnya. Hari ini telah banyak penelitian yang menunjukkan peran media massa dan pengaruhnya dalam kehidupan sehari-hari. Kebutuhan akan surat kabar, radio, televisi, bioskop, commercial break atau iklan ditambah dengan kemajuan multimedia melalui internet menghadirkan fenomena baru di setiap sisi kehidupan manusia.

Media massa atau komunikasi massa dapat di definisikan dengan memusatkan perhatian pada lima variabel yang terkandung dalam setiap tindak komunikasi dan memperlihatkan bagaimana varibel-variabel ini bekerja pada media massa (Devito, 1997:506). Pertama, sumber: komunikator massa adalah suatu organisasi komplek yang mengeluarkan biaya besar untuk menyusun dan mengirimkan pesan. Kedua, khalayak: massa atau orang banyak yang bersifat heterogen, anonim, dan luas. Pesan dari komunikasi massa harus fokus pada pemirsa atau khalayak rata-rata yang dengan hal ini media dapat merangkul khalayak sebanyak mungkin. Ketiga,Pesan: komunikasi Massa merupakan milik umum, komunikasi massa dapat dilihat dan didengar oleh setiap orang yang diterpanya. Keempat, Proses: ada dua proses dalam komunikasi massa yaitu, proses mengalirnya pesan yang pada dasarnya merupakan proses satu arah dimana pesan mengalir dari media kepada penerima atau khalayak tetapi tidak memiliki umpan balik. Kedua proses seleksi atau dua arah, baik media maupun khalayak melakukan seleksi, dimana media menyeleksi bagian dari total populasi yang akan mereka raih. Selanjutnya Pemirsa atau pembaca atau pendengar akan menseleksi dari semua media yang ada, pesan tertentu akan mereka ikuti seperti khalayak Femina, otomotif, Angkasa, kontan atau HighEnd. Kelima, Konteks: komunikasi massa berlangsung dalm suatu konteks sosial. Media mempengaruhi konteks sosial dan konteks sosial mempengaruhi media. Dengan kata lain, terjadi hubungan transaksional antara media dan masyarakat. Masing-masing mempengaruhi yang lain (ibid, hal:507).

Bentuk-bentuk komunikasi massa diantaranya, Televisi, Radio, surat kabar, majalah, buku, dan Film. Saat ini fungsi komunikasi massa untuk menghibur, media mendesain program mereka untuk memberi hiburan dan mendapat perhatian dari khalayaknya. Meyakinkan, media massa berusaha meyakinkan (to persuade), mengukuhkan atau memperkuat sikap, kepercayaan atau nilai seseorang, mengubah sikap, kepercayaan atau nilai seseorang, menggerakkan seseorang untuk melakukan sesuatu, dan memperkenalkan etika, atau menawarkan sistem nilai tertentu.

Dalam perkembangannya, media massa mengemas sebuah kampanye politik menjadi sangat menarik dan kreatif. Media massa telah mengambil peran yang sangat signifikan di dalam ranah politik, bahkan media massa telah menjadi aktor utama dalam bidang politik. 
Media mampu membangun citra seseorang dalam karir politiknya. Setiap yang memiliki kepentingan politik, baik personal maupun kolektif, tidak pernah luput dari media sebagai instrumen aktivitasnya. Harorld D. Laswell mengidentifikasi media massa pada tiga fungsi utama: pertama, fungsi pengawasan. Merujuk pada aktifitas media massa dalam mencermati dan melaporkan peristiwa-peristiwa penting kepada publik. Kedua,fungsi penghubung, lebih pada peran media massa sendiri sebagai sarana berdiskusi, saling bertukar pendapat, dan aspirasi bagi seluruh kelompok masyarakat. Ketiga, fungsi transmisi warisan sosial. Peran media massa dalam proses sosialisasi nilai, norma, dan kesepakatan yang berkembang di masyrakat demi keutuhan dan terpeliharanya aturan sosial; serta edukasi bagi masyarakat luas (Tabroni,2014:96).

Kajian yang lebih baru mengenai fungsi politik media massa banyak dilakukan dengan mengaitkannya dengan upaya pengembangan demokrasi. Media massa memiliki peran signifikan dalam upaya pengembangan sistem demokrasi multi partai. Pers atau media massa menumbuhkan kesadaran akan nilai-nilai demokrasi dikalangan masyarakat termasuk kalangan elite politik. Pawito dalam Tabroni, 2014 mengutip pemikiran Curran (1991) mengenai identifikasi enam fungsi Pers dalam upaya mengembangkan demokrasi, yakni: pertama, menyediakan forum untuk debat publik. Kedua, mengartikulasikan pendapat umum. Ketiga, memaksa pemerintah mempertimbangkan apa yang dipikirkan dan dikehendaki oleh rakyat. Keempat, mendidik warga negara untuk memiliki informasi yang memadai bagi pengambilan keputusan dalam pemilihan umum. Kelima, memberikan kepada publik saluran komuniasi politik di antara berbagai kelompok masyarakat yang memiliki kepentingan yang berbeda-beda. Keenam, membela individu-individu melawan penyalahgunaan kekuasaan yang dilakukan oleh kalangan eksekutif dan kekuasaan lainnya.

Retorika atau metode kampanye konvensional seperti pengerahan massa untuk mensosialisasikan program dan membangun citra politik bakal calon di panggung-panggung terbuka mulai terasa tidak efektif dan efisian dari segi waktu dan biaya. Keriuhan ide, gagasan, dan visi-misi mulai berpindah ke ruang maya. Diskusi, perdebatan bahkan fitnah secara frontal begitu bebas terjadi di media sosial.

Pemilihan umum legislatif (pileg) tahun 2009 merupakan pemilu paling ramai diwarnai kampanye lewat media internet. Untuk pertama kalinya beberapa kandidat legislatif memiliki media sendiri yang dikelola secara virtual. Para caleg memiliki blog yang dibuat, baik oleh dirinya sendiri maupun oleh tim suksesnya. Isinya sangat beragam, ada yang menampilkan profilnya saja, ada juga yang dilengkapi dengan program-program atau janjijanji. Pada umumnya, keberadaan blog tersebut hanya untuk kepentingan kampanye, pasalnya pasca pileg blog tersebut tidak aktif lagi. Jika pun ada politikus masih aktif, blog tersebut cenderung monoton dan kurang dinamis. Selain profil kandidat, partai pendukung, visi-misi dan program, konten dari situs ini adalah berbagai kegiatan atau agenda yang akan dilakukan pada masa kampanye (ibid).

Jue, Arthur L, et all (2010): 42, menjelaskan bahwa:

"social computing technologies has enabled it to speed up its communication and elicit broad perspectives from members much faster than it could with traditional e-mail and meeting methods. Aside from the speed of obtaining relevant information, there has 
been an increase in the consistency and quality of members' work, as social media provided a new method by which to connect and collaborate with test experts. Members also feel as if they belong to a larger community, which gives them a sense of greater personal and professional benefit".

Teknologi komputerisasi secara sosial telah memungkinkannya untuk mempercepat komunikasi dan memperoleh perspektif luas dari anggotanya, jauh lebih cepat daripada email dan pertemuan tradisional lainnya. Selain kecepatan memperoleh informasi yang relevan, ada peningkatan dalam konsistensi dan kualitas kerja anggota komunitas, karena media sosial menyediakan metode baru untuk menghubungkan dan berkolaborasi dengan para ahli yang sudah teruji. Anggota juga merasa seolah-olah mereka berasal dari komunitas yang lebih besar, yang memberi mereka rasa manfaat pribadi dan profesional yang lebih besar. Dengan kata lain sosial media adalah berbagai media elektronik yang mampu meningkatkan akselerasi dan kemampuan koneksi setiap orang untuk terhubung, berkomunikasi, dan berkolaborasi (ibid, hal:44).

Facebook, twitter, instagram, whatsapp dan youTube termasuk dalam media sosial sebagai bentuk akselerasi pada koneksivitas dan informasi yang diakses melalui internet. Toffler dan Gun dalam Tabroni, 2014:153 menggambarkan bahwa sistem komunikasi komputer akan meningkatkan partisipasi secara luas dan pemerataan dalam kehidupan sosial dengan mengizinkan untuk megkases informasi dengan mudah. Berikut ini sejumlah kelebihan yang dimiliki media internet antara lain:

1) Menembus batas wilayah, ruang dan waktu

2) Memperluas akses memperoleh informasi global

3) Meningkatkan kemampuan untuk berserikat secara bebas

4) Mengancam tatanan yang telah mapan, seperti pemerintahan otokrasi

5) Memiliki kecepatan perkembangan dan penyebaran yang sulit diatasi

Pengklusteran media massa dan media sosial yang akan menjadi akses informasi pemilih mengenai kampanye di Kota Tanjungpinang, sebagai berikut:

Tabel 2. Kluster Media Massa (Konvensional) dan Media Sosial (New Media)

Kota Tanjungpinang

\begin{tabular}{|c|l|l|l|l|}
\hline No & \multicolumn{2}{|c|}{ Media Massa } & \multicolumn{2}{|}{ Media Sosial } \\
\hline 1 & Elektronik & Televisi: & Media & 1. Facebook \\
& & 1. Tanjungpinang TV & sosial & 2. Instagram \\
& & 2. Ficom TV & 3. Whatsapp \\
& & 3. TV Kepri & 4. Twitter \\
& & Radio: & 5. Line \\
& & 1. RRI programa 1 & & \\
& & Tanjungpinang & & \\
\hline 2 & Cetak & 2. Pandawa Radio & & \\
& & Tanjungpinang Pos & Media & 1. Batam news.co.id \\
& & & 2. Batampos.co.id \\
\hline
\end{tabular}




\begin{tabular}{|l|l|l|l|}
\hline & Batam Pos & & 3. Posmetro.co \\
& Haluan Kepri & 4. Metrobatam.com \\
& & 5. Wartakepri.co.id \\
& & 6. Karimuntoday.com \\
& & 7. Lendoot.com \\
& & 8. Sijorikepri.com \\
\hline
\end{tabular}

\section{METODOLOGI PENELITIAN}

Jenis metode penelitian yang digunakan di dalam penelitian ini yaitu metode deskriptif dengan pendekatan kuantitatif, artinya penelitian yang dilakukan adalah menekankan analisanya pada data-data numeric (angka). Menurut Sugiyono (2014:7-8), metode penelitian kuantitatif adalah pendekatan ilmiah / scientific yang memandang realitas / gejala / fenomena itu dapat diklasifikasikan karena telah memenuhi kaidah-kaidah ilmiah yaitu relatif tetap, konkrit/empiris, obyektif, terukur, rasional, dan sistematis, dimana data penelitiannya berupa angka-angka dan analisis menggunakan statistik.

Data di dalam penelitian ini yaitu dengan menggunakan angket. Adapun angket yang digunakan di dalam penelitian ini berupa pertanyaan terbuka dan pernyataan tertutup, dimana peneliti mengharapkan responden untuk memilih salah satu alternatif jawaban serta memberikan jawaban singkat dari setiap pertanyaan yang telah tersedia. Pemetaan penggunaan media massa dan media sosial dalam mengakses Informasi kampanye pilkada Kota Tanjungpinang 2018 dilaksanakan dengan menentukan sampel pemilih kota Tanjungpinang dari dari Populasi rekapitulasi pemilih di 4 kecamatan kota Tanjungpinang. Berdasarkan data KPU kota Tanjungpinang per Maret 2018, jumlah pemilih mencapai 144.241 orang. Pengambilan sampel dalam penelitian ini menggunakan teknik multi-stage stratified random sampling, hal ini disebabkan DPS berasal dari beberapa kecamatan dan populasi berjumlah cukup besar serta heterogen.

Responden penelitian ini terdiri dari pemilih yang terdaftar dan dipilih secara acak dari perwakilan TPS yang ada di Kota Tanjungpinang di setiap kecamatan. terpilih 86 di TPS Kecamatan Bukit Bestari, 86 di Kecamatan Tanjungpinang Barat, 86 di Kecamatan Tanjungpinang Kota dan 90 responden dari TPS Kecamatan Tanjungpinang Timur

\section{HASIL DAN PEMBAHASAN}

Penelitian ini bertujuan untuk mengetahui peta pengguna media massa dan media sosial bagi pemilih di Kota Tanjungpinang sebagai saluran media komunikasi politik dalam pemilihan kepala daerah walikota dan wakil walikota Tanjungpinang pada tahun 2018.

Berdasarkan kelompok usia, data responden dalam penelitian ini dapat digambarkan dalam grafik beriku ini: 


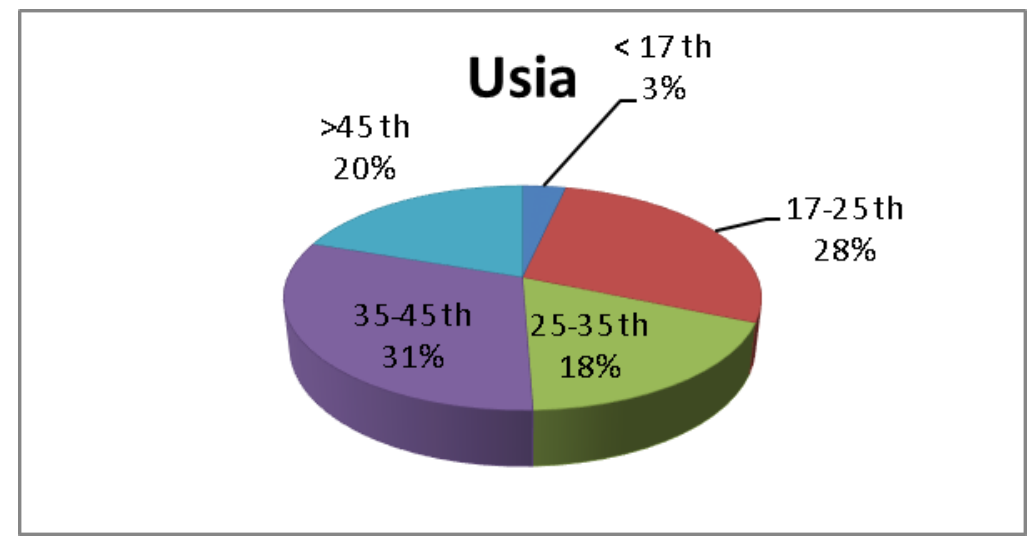

Gambar 1. Profil Responden berdasarkan kelompok Usia

Dari grafik di atas dapat dilihat bahwa $31 \%$ responden pemilih pengguna media massa dan media sosial sebagai saluran komunikasi politik pada pilkada walikota Tanjungpinang 2018 berusia 35-45 tahun. Diurutan berikutnya tercatat $28 \%$ responden pemilih berusia $17-$ 25 tahun, 20\% responden pemilih berusia lebih atau diatas 45 tahun, $18 \%$ responden pemilih berada di usia 25-35 tahun dan hanya $3 \%$ responden pemilih yang berusia dibawah 17 tahun.

Berdasarkan jenis kelamin, pemilih yang menjadi responden dalam penelitian ini terdiri dari 196 orang perempuan dan 151 orang laki-laki, dengan total 347 orang. Pemetaan jenis kelamin responden dapat dilihat dalam gambar berikut:

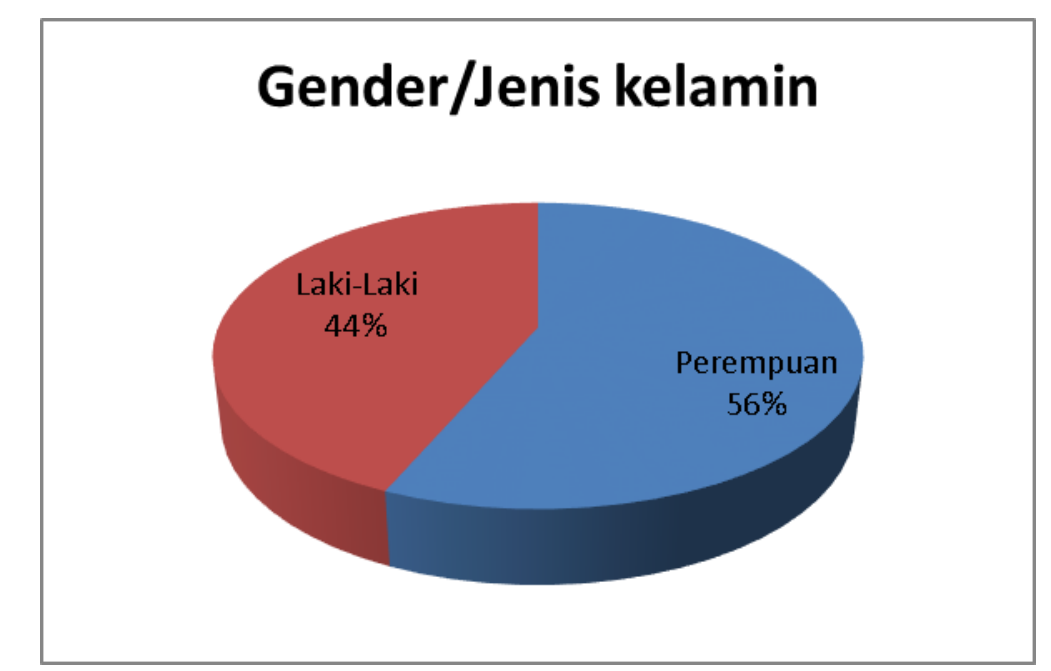

Gambar 2. Profil Responden berdasarkan Jenis Kelamin

Selain perbandingan persentase jenis kelamin yang telah dideskripsikan di atas, profil responden juga diuraikan meurut jenis pekerjaannya, seperti yang tertera di dalam. Pemetaan mengenai jenis pekerjaan responden di atas dapat divisualisasikan ke dalam grafik berikut ini: 


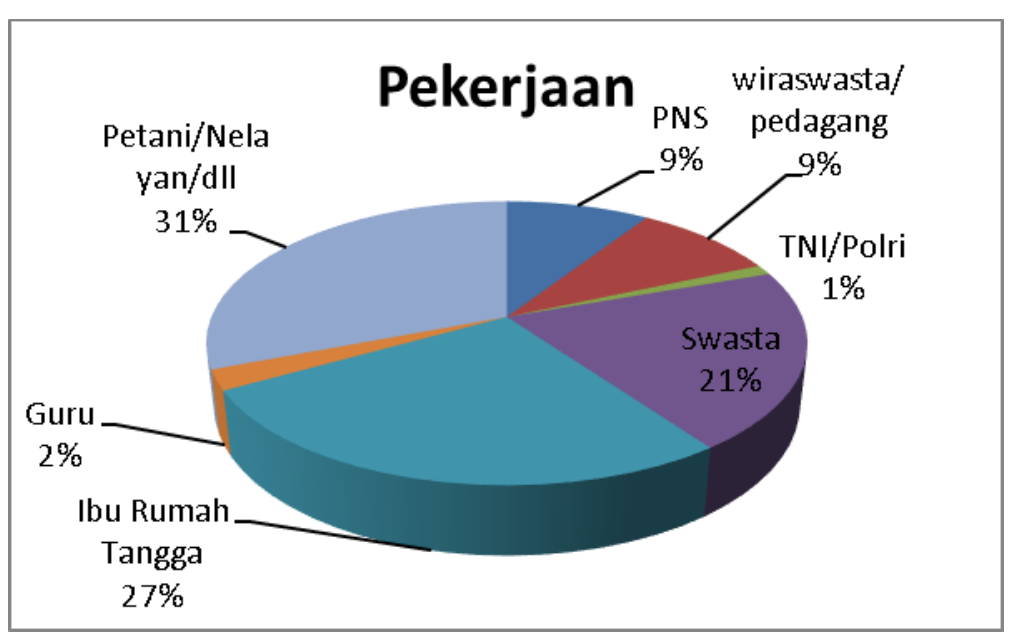

Gambar 3. Profil Responden berdasarkan Pekerjaan

Pekerjaan responden pemilih sekira 31\% Petani/Nelayan/Dll, kemudian 27\% adalah Ibu Rumah Tangga, 21\% bekerja di Swasta, lalu 9\% adalah PNS sebanding dengan 9\% Wiraswasta/pedagang, dan $2 \%$ sebagai Guru terakhir $1 \%$ TNI/Polri.

Dari jenis pekerjaan responden di atas, data mengenai jumlah penghasilan responden dapat dirincikan sebagai berikut: Penghasilan responden pemilih di Kota Tanjungpinang $62 \%$ berada di 1-3 Juta Rupiah, 21\% kurang dari 1 Juta rupiah dan 17\% berpenghasilan diatas 3 Juta Rupiah. Perbandingan persentase tersebut dapat dilihat secara lebih jelas di dalam grafik berikut:

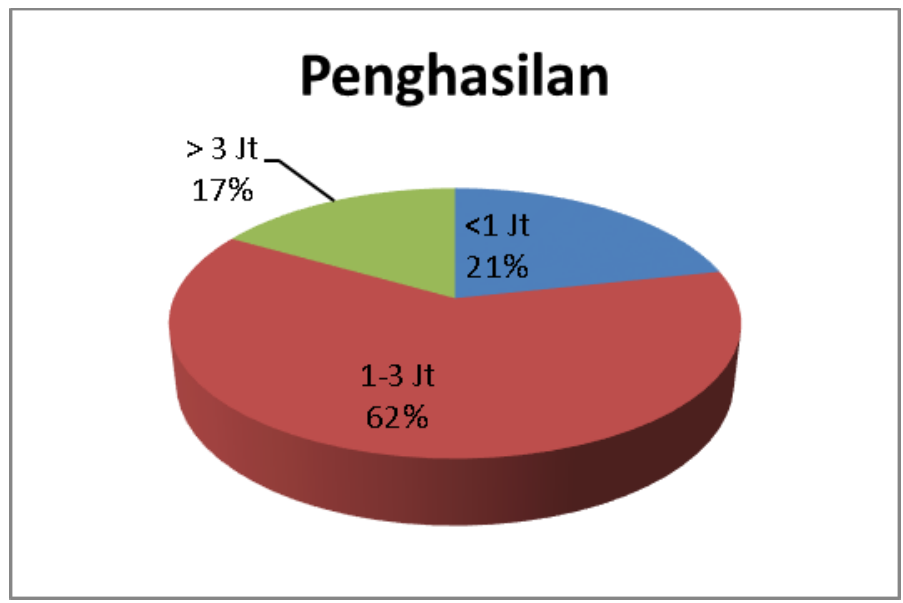

Gambar 4. Profil Resonden berdasarkan penghasilan

Penghasilan responden pemilih di Kota Tanjungpinang 62\% berada di 1-3 Juta Rupiah, $21 \%$ kurang dari 1 Juta rupiah dan $17 \%$ berpenghasilan diatas 3 Juta Rupiah. Perbandingan persentase tersebut dapat dilihat secara lebih jelas di dalam grafik berikut: 


\section{Penggunaan Media Massa dan Media Sosial bagi Pemilih pada Pilkada Walikota Tanjungpinang 2018}

Berdasarkan hasil survei terhadap pemilih atau voter pada pilkada walikota Tanjungpinang 2018 lalu, melalui angket yang disebarkan kepada 347 responden di 4 TPS yang mewakili 4 kecamatan di Kota Tanjungpinang dapat diperoleh informasi mengenai penggunaan atau konsumsi para pemilih kota Tanjungpinang terhadap media massa dan media sosial sebagai saluran komunikasi politik kampanye pilwako kota Tanjungpinang 2018, adapun hasilnya sebagai berikut:

\section{Penggunaan Media Massa: Elektronik}

Media massa elektronik yang ada di Tanjungpinang terdiri atas Pandawa FM, RRI Prog 1 Tanjungpinag, Ficom TV, TV Kepri dan Tanjungpinang TV. Dari hasil penelitian yang telah dilakukan, pemetaan responden dalam menggunakan media massa elektronik dalam kehidupan sehari-hari yaitu sebagai berikut:

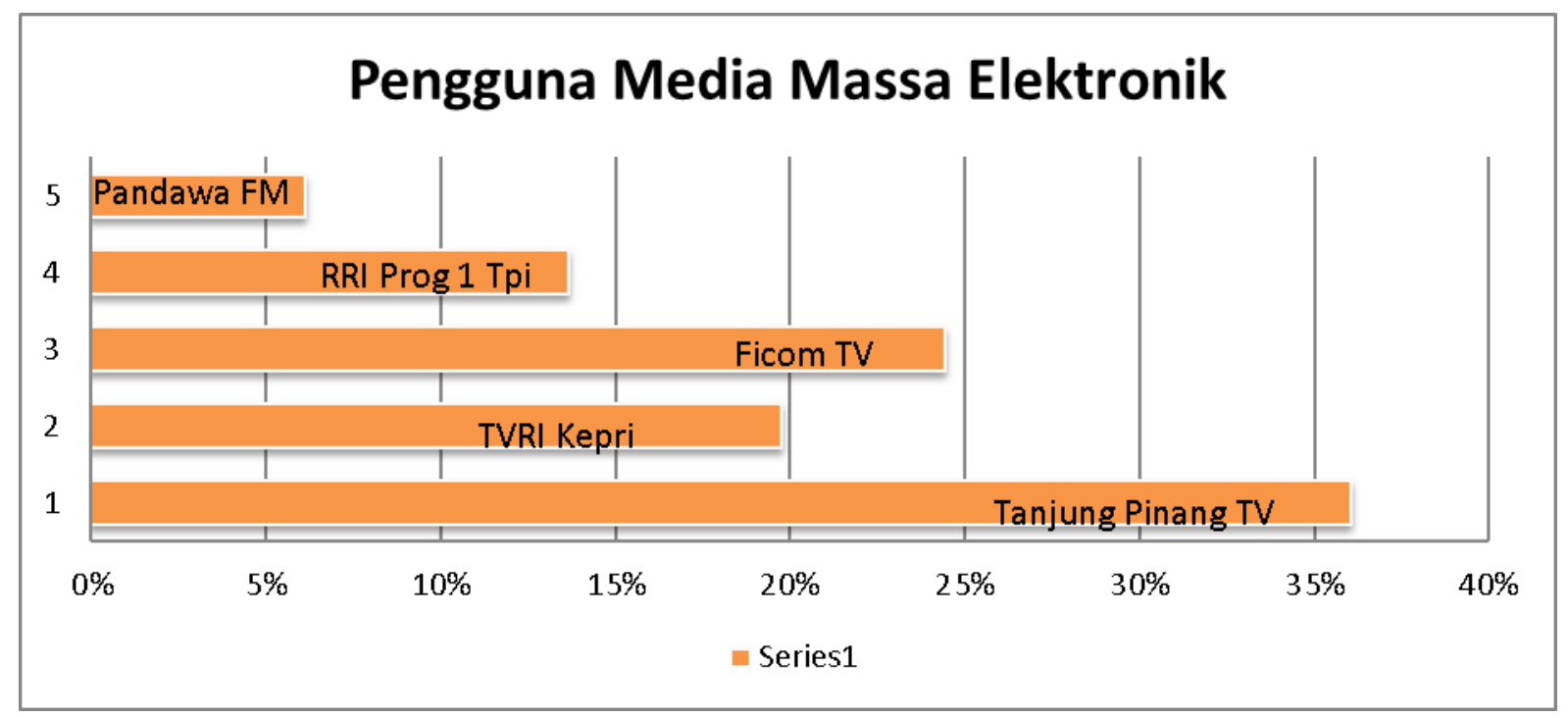

Gambar 5. Pengguna Media Massa Elektronik

Tanjungpinang TV merupakan media massa elektronik yang medominasi konsumsi pemilih guna memperoleh informasi kampanye mengenai pilwako dengan frekuensi 177 kali frekuensi jawaban dari 347 Responden atau sama dengan 36\% dibandingkan dengan Ficom TV 24\%, TVRI Kepri 20\%, RRI Prog 1 Tanjungpinang 14\% dan Radio Pandawa FM 6\% dari jawaban dominasi.

\section{Pengguna Media Massa: Cetak}

Media massa cetak yang ada di Tanjungpinang terdiri dari media massa cetak Haluan Kepri, Batam Pos dan Tanjungpinang Pos. Data mengenai pengguna media massa cetak dalam mengakses informasi mengenai kampanye yang ada di Tanjungpinang dapat dilihat di dalam gambar berikut: 


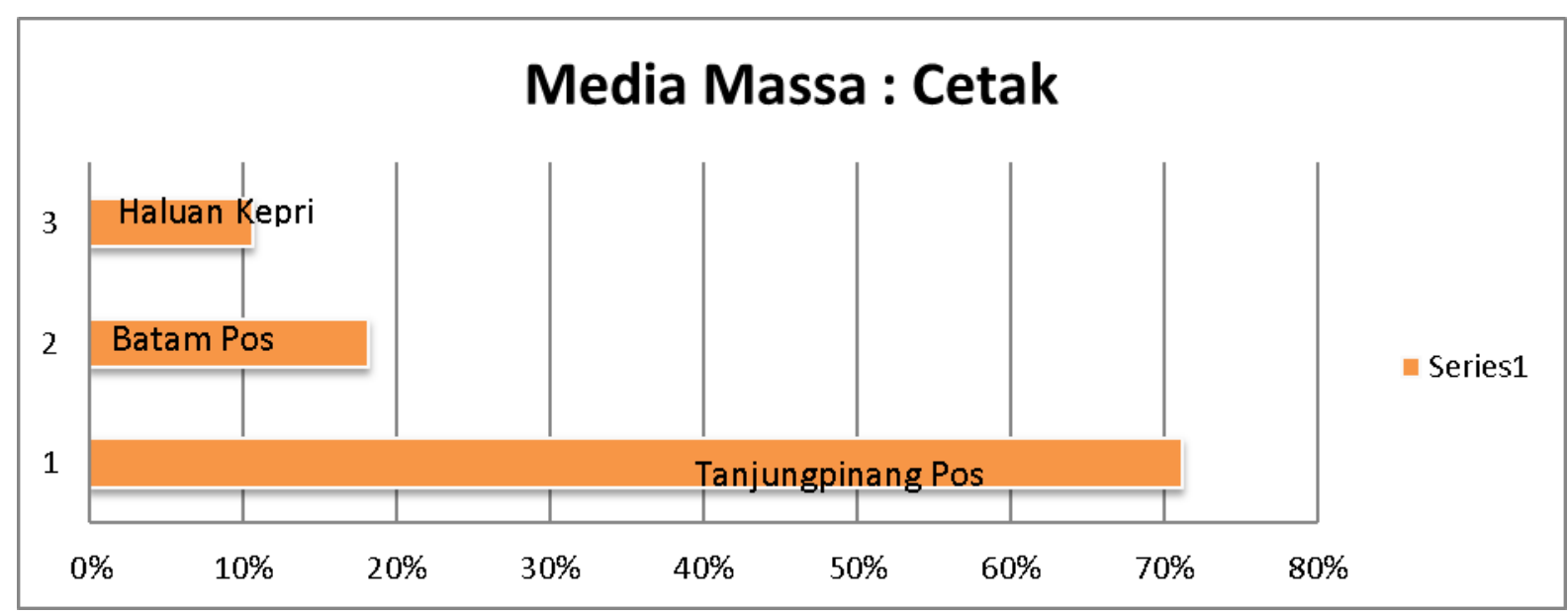

Gambar 6. Pengguna Media Massa Cetak

Media masaa cetak Tanjungpinang Pos mendominasi jawaban pengguna media Cetak bagi pemilih kota Tanjungpinang sebesar $71 \%$ atau 188 kali frekuensi jawaban dari 347 responden dibandingkan dengan harian Batam Pos $18 \%$ dan Haluan Kepri $11 \%$.

\section{Pengguna Media Sosial}

Secara umum, media sosial terdiri atas Twitter, Line, Instagram, Whatsapp dan Facebook, tidak terkecuali dengan media sosial mayoritas yang digunakan oleh responden di dalam penelitian ini. Berdasarkan hasil penelitian yang telah dilakukan, dominasi pengguna media sosial dapat dilihat di dalam gambar berikut:

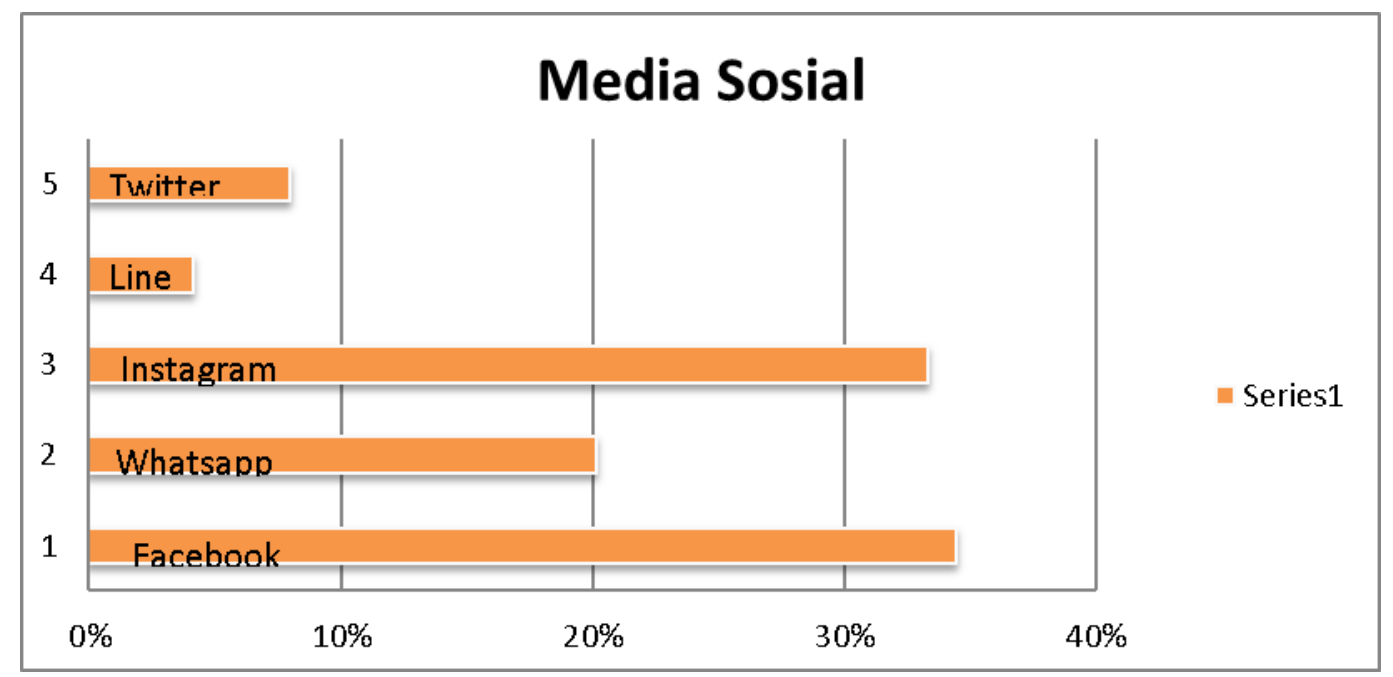

Gambar 7. Pengguna Media Sosial

Untuk media sosial, Facebook mendominasi jawaban pengguna Media Sosial bagi pemilih kota Tanjungpinang. 207 kali frekuensi jawaban dari 347 responden atau sama dengan 34\% jawaban dominasi. Sedangkan Instagram 33\%, Whatsapp 20\%, twitter $8 \%$ dan Line $4 \%$ dari frekuensi jawaban dominasi. 


\section{Pengguna Media Massa Online}

Media massa online di Tanjungpinang terdiri atas SijoriKepri.com, Lendot.com, Karimuntoday.com, wartakepri.co.id, metrobatam.com, posmetro.co.id, batampos.co.id dan batamnews.co.id. Dari hasil penelitian yang telah dilakukan, dominasi media massa online yang digunakan di Tanjungpinang yaitu sebagai berikut:

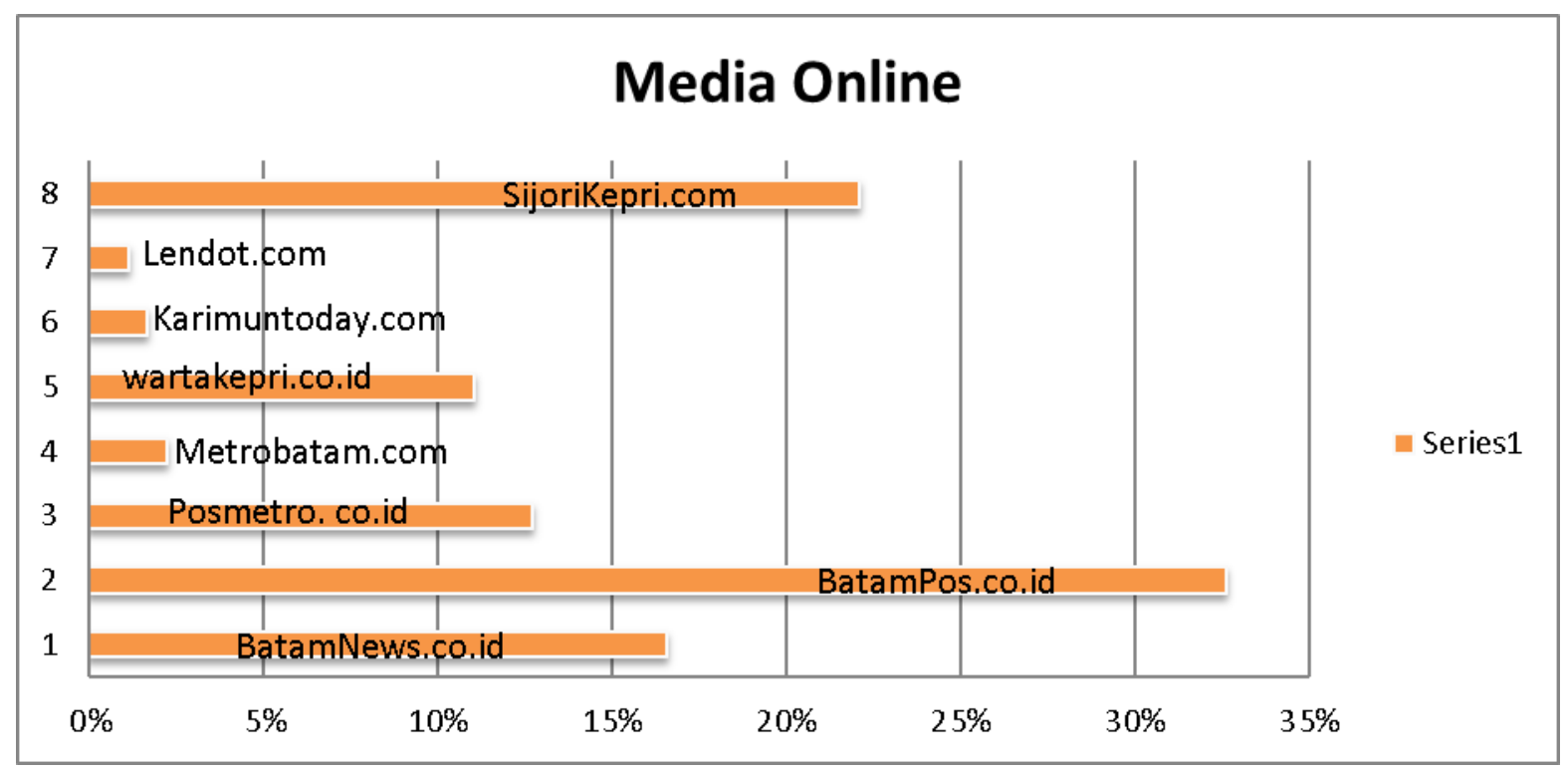

Gambar 8. Pengguna Media Massa Online

Media berita Online di dominasi oleh BatamPos.co.id mendominasi jawaban pengguna Media Sosial bagi pemilih kota Tanjungpinang. 59 kali frekuensi jawaban dari 347 responden atau sama dengan 33\% jawaban dominasi. Disusul dengan Sijorikepri.com $22 \%$, BatamNews.co.id 17\%, Posmetro.co.id 13\%, Wartakepri.co.id 11\%, Metrobatam.com $2 \%$, Karimuntoday.com $2 \%$, dan Lendot.com $1 \%$.

\section{Alasan menggunakan media massa elektronik dan cetak bagi pemilih}

Penggunaan media cetak dan elektronik oleh pemilih dalam mengakses informasi mengenai pasangan calon walikota ditinjau berdasarkan karakteristik yang dimiliki oleh media massa cetak dan elektronik. Berdasarkan indikator yang ada, dominasi alasan penggunaan media massa cetak dan elektronik oleh pemilih dalam mengakses informasi mengenai pasangan calon walikota Tanjungpinang tahun 2018 dapat dilihat pada gambar berikut: 


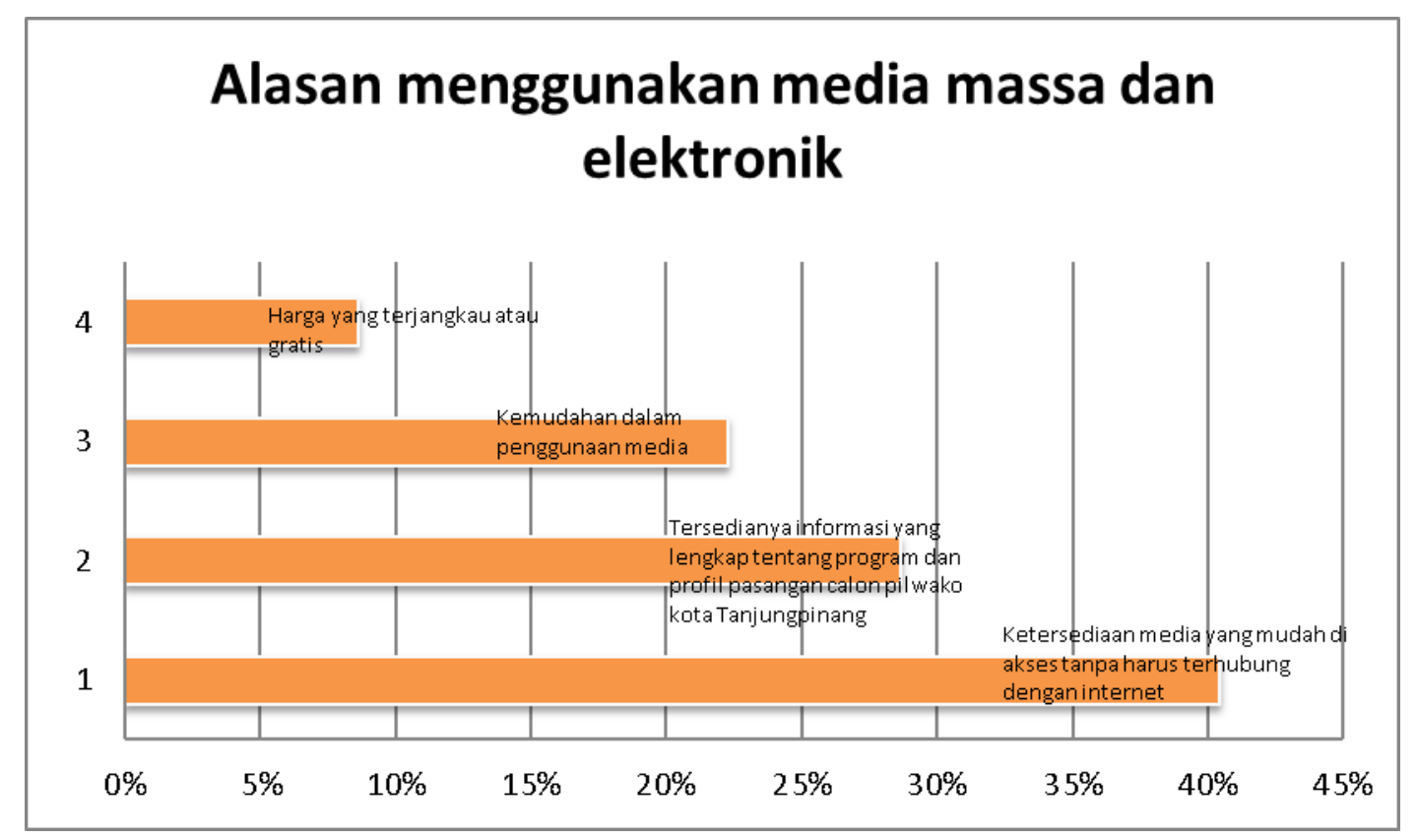

Gambar 9. Alasan menggunakan media massa cetak dan elektronik

Adapun sebagai tambahan informasi mengenai alasan pemilih dalam menggunakan media massa baik media elektronik dan cetak sebagai saluran komunikasi politik mengenai pilkada walikota Tanjungpinang 2018, ditemukan hasil angket Kemudahan akses tanpa harus terhubung dengan internet mendominasi jawaban. Artinya, alasan tersebut dipilih 127 kali frekuensi jawaban dari 347 responden atau sama dengan 40\% jawaban dominasi. Disusul dengan alasan tersedianya informasi yang lengkap tentang program dan profil pasangan calon walikota Tanjungpinang sekira $29 \%$, lalu alasan kemudahan dalam penggunaan media $22 \%$ dan terakhir alasan harga yang terjangkau atau gratis $9 \%$.

\section{Alasan menggunakan media sosial dan Online bagi pemilih}

Selain media cetak dan elektronik, zaman milenial ini justru lebih banyak diwarnai dengan media sosial dan online dalam kehidupan msyarakat sehari-hari, bahkan dalam kehidupan politik. Bahkan media sosial dan media online menjadi strategi dalam kampanye politik. Berdasarkan survey yang telah dilakukan mengenai jenis media sosial yang dominan digunakan untuk memperoleh informasi mengenai pasangan calon dalam pemilihan wali kota Tanjungpinang tahun 2018 yaitu sebagai berikut. 


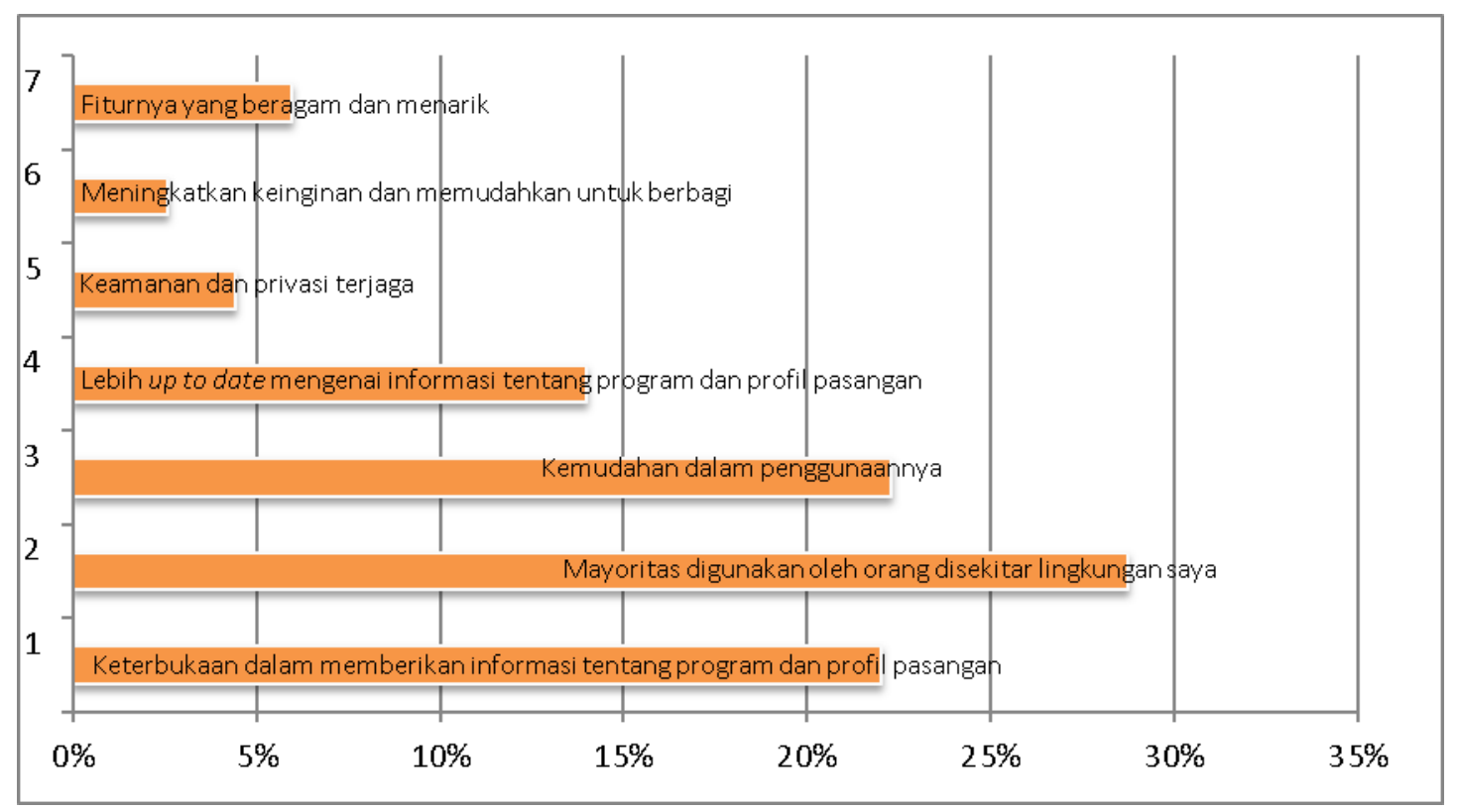

Gambar 10. Alasan menggunakan media sosial dan online

Untuk media Sosial dan Online, pemilih menggunakan media tersebut sebagai saluran komunikasi politik atau sumber informasi mengenai pasangan calon walikota Tanjungpinang 2018 dengan alasan mayoritas digunakan oleh orang disekitar lingkungan saya sebagai pilihan jawaban yang mendominasi hingga 111 kali frekuensi jawaban dari 347 responden atau sama dengan 29\% jawaban dominasi. Diikuti oleh alasan kemudahan dalam penggunaannya sebanyak $22 \%$, frekuensi jawaban yang sama alasan keterbukaan dalam memberikan informasi tentang program dan profil pasangan sebanyak $22 \%$, juga dipilih untuk alasan Lebih up to date mengenai informasi tentang program dan profil pasangan calon pilwako kota Tanjungpinang dengan 14\%, fitur yang beragam dan menarik 6\%, keamanana dan privasi terjaga $4 \%$ dan pilihan alasan terakhir meningkatkan keinginan dan memudahkan untuk berbagi $3 \%$.

Informasi yang paling ingin diperoleh dengan menggunakan media massa dan media sosial tentang program dan profil pasangan calon pilwako kota Tanjungpinang bagi Pemilih kota Tanjungpinang

Kampanye merupakan salah satu cara untuk mendulang suara. Seringkali kampanye dilakukan tidak dengan secara langsung, melainkan dengan menggunakan media. Media sebagai perantara akan mengangkat isu mengenai pasangan calon yang ikut di dalam pilkada. Menurut Suranto (2008) dalam tulisannya yang berjudul Kritis Meliput Pemilu, beberapa isu penting yang ada di dalam liputan media di antaranya yaitu sebagai berikut:

a. Apa visi misi pasangan calon yang penting diketahui oleh pemilih?

b. Bagaimana profil dan rekam jejak pasangan calon tersebut?

c. Apa program pasangan calon yang penting untuk diketahui pemilih?

d. Bagaimana gaya kepemimpinan pasangan calon tersebut?

e. Bagaimana ideologi pasangan calon tersebut? 
Berdasarkan survey yang telah dilakukan, pemetaan kelima indikator mengenai isu penting mengenai pasangan calon pemilihan walikota Tanjungpinang tahun 2018 yang ingin diketahui oleh pemilih yaitu sebagai berikut:

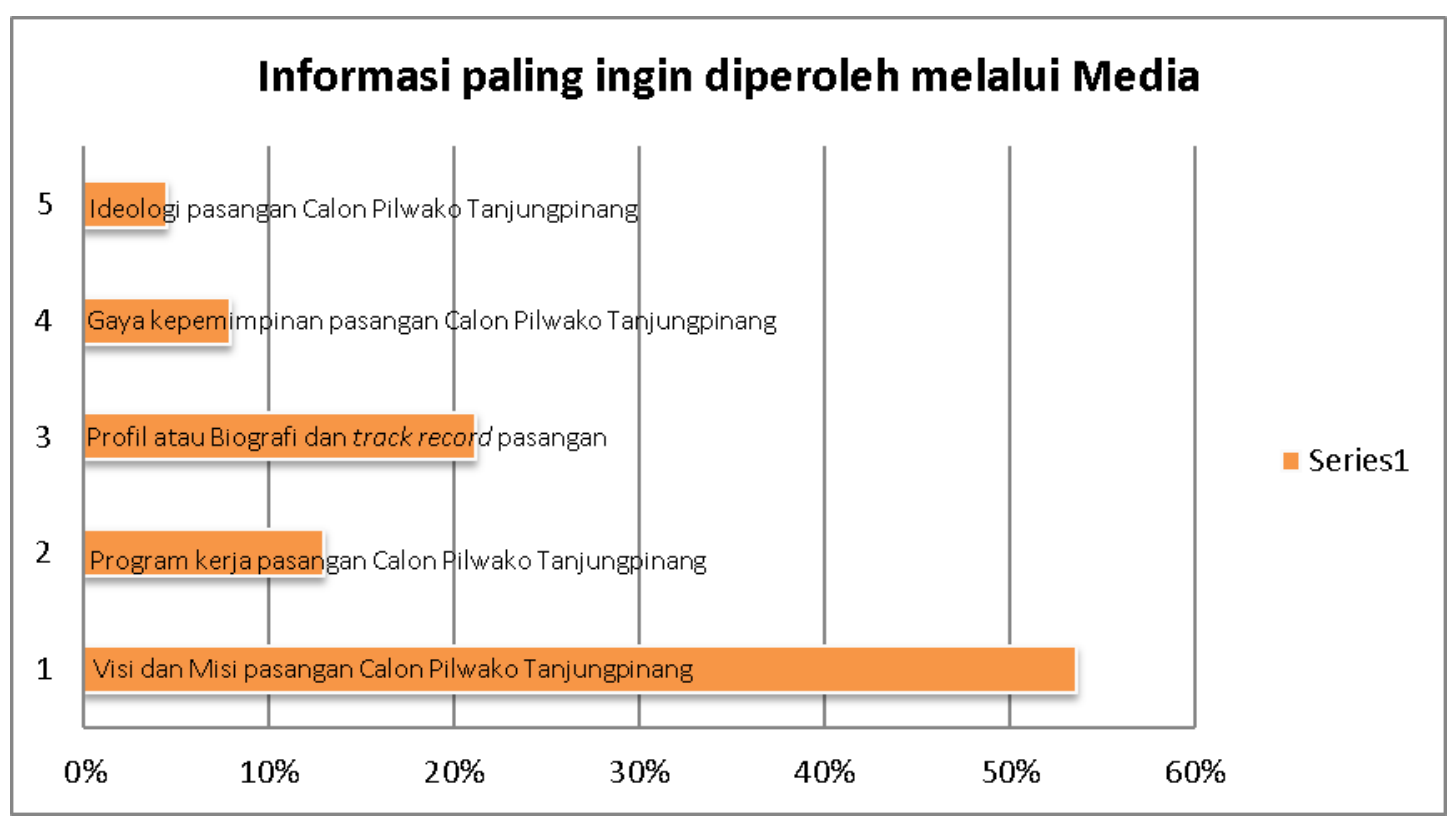

Gambar 11. Informasi yang Paling Ingin Diperoleh Melalui Media

Dimensi terakhir dari angket survei ini ditemukan bahwa informasi apa yang paling ingin diperoleh responden pemilih dengan menggunakan media massa dan media sosial tentang program dan profil pasangan calon pilwako kota Tanjungpinang bagi Pemilih kota Tanjungpinang adalah Visi dan Misi pasangan calon Pilwako Tanjungpinang mendominasi jawaban, 203 kali frekuensi jawaban dari 347 responden atau sama dengan 54\% jawaban dominasi. Profil atau Biografi dan track record pasangan Calon Pilwako Tanjungpinang menjadi informasi berikutnya yang ingin diperoleh pemilih dengan jumlah dominasi pilihan jawaban 21\%. Program kerja pasangan calon pilwako Tanjungpinang memiliki 13\% pilihan jawaban responden. Gaya kepemimpinan pasangan Calon Pilwako Tanjungpinang memiliki $8 \%$ pilihan jawaban untuk informasi yang ingin diperoleh dan yang paling akhir Ideologi pasangan Calon Pilwako Tanjungpinang dengan 4\% saja.

\section{PENUTUP}

Berdasarkan data survei pengguna media Massa dan Media Sosial sebagai Saluran Komunikasi Politik pada Pilkada Kota Tanjung Pinang 2018, disimpulkan bahwa Pemetaan yang tertera menunjukkan bahwa media sosial facebook adalah media sosial yang paling banyak digunakan oleh responden dalam mengakses informasi mengenai pasangan calon walikota dan wakil walikota Tanjungpinang pada tahun 2018 dengan frekuensi sebesar 207 orang responden, bahkan penggunaan media sosial facebook paling dominan daripada mayoritas pengguna media elektronik yaitu Tanjungpinang TV yang digunakan oleh 177 orang responden atau dan media cetak Tanjungpinang Pos yaitu sebanyak 188 orang serta 
media online Batampos.co.id yang hanya berjumlah 59 orang dari keseluruhan responden. Artinya, media komunikasi politik yang paling dominan digunakan oleh pesmilih di kota Tanjungpinang dalam mengakses kampanye pemilihan walikota tahun 2018 yaitu media sosial Facebook.

Alasan penggunaan media Sosial dan media Online sebagai Saluran Komunikasi Politik pada Pilkada Kota Tanjung Pinang 2018, didominasi oleh alasan kemudahan dalam pengguanaanya dengan frekuensi dominasi jawaban 111 kali atau 32\%. Informasi yang paling ingin diperoleh dengan menggunakan media Massa dan media Sosial tentang program dan profil pasangan calon pilwako kota Tanjungpinang bagi Pemilih kota Tanjungpinang sebagai Saluran Komunikasi Politik pada Pilkada Kota Tanjung Pinang 2018, di dominasi Visi dan Misi pasangan calon Pilwako Tanjungpinang dengan frekuensi 203 kali 59\%.

Hasil penelitian yang telah dilakukan memperlihatkan bahwa media sosial facebook merupakan media komunikasi politik yang paling dominan digunakan oleh pemilih di kota Tanjungpinang dalam mengakses kampanye pemilihan walikota tahun 2018, dengan alasan kemudahan dalam pengguanaanya. Penelitian ini merupakan hasil awal untuk melihat persepsi khalayak tentang penggunaan new media pada kampanye pemilu dan pilkada di masa yang akan datang.

\section{REFERENSI}

Fachrizan. 2015. Peran Media Massa dalam Pemilihan Legislatif Tahun 2014 di Kota Tanjungpinang. Skripsi. Universitas Maritim Raja Ali Haji

Hikmat, Mahi M. 2011. Komunikasi Politik Teori dan Praktik. Bandung: Simbiosa Rekatama Media

Indografis Database. http://isparmo.web.id/2016/11/21/data-statistik-pengguna-internetindonesia-2016. diakses tanggal 20 Maret 2018

McQuail, Denis, 2000. Mass Communication Theories, Fourth edition, Sage Publication, London

Nugroho, Yanuar dan Syarief, Sofie Shinta. 2012. Beyond Click-Activism?: New Media and Political Processes in Contemporary Indonesia. Berlin: Friederich-Ebert Stiftung.

Peraturan Komisi Pemilihan Umum Republik Indonesia Nomor 1 Tahun 2017 tentang Tahapan, Program dan Jadwal Penyelenggaraan Pemilihan Gubernur dan Wakil Gubernur, Bupati dan Wakil Bupati, dan/atau Walikota dan Wakil Walikota Tahun 2018

Pureklolon, Thomas Tokan.2016. Komunikasi Politik "Mempertahankan Integritas Akademisi, Politikus, dan Negarawan".Jakarta: PT Gramedia Pustaka Utama

Sri Nuryanti. 2015. Intervensi Penyelenggaraan Pemilukada: Regulasi, Sumberdaya dan Eksekusi. JSP UGM Volume 19, Nomor 2, November 2015 (125-140)

Sugiyono, 2014, Metode Penelitian Kuantitatif Kualitatif dan R\&D. Bandung:ALFABETA

Tabroni, Roni.2014. Komunikasi Politik pada era Multimedia. Bandung: Simbiosa Rekatama Media

Tankard, James W dan Werner J. Severin.2001. Teori Komunikasi: Sejarah, Metode dan Terapan di dalam Media Massa, Edisi Kelima. Jakarta: Prenada Media 
Undang-Undang Nomor 32 Tahun 2004 tentang Pemerintah Daerah

Venus, Antar. 2012. Manajemen Kampanye "Panduan Teoretis dan Praktis dalam megefektifkan Kampanye Komunikasi”. Bandung: Simbiosa Rekatama Media 